\title{
Influence of experimental fires on mesofauna communities (Collembola and Acari) of two types of meadows ${ }^{\star}$
}

\author{
Wpływ doświadczalnych pożarów na zespoły mezofauny \\ (Collembola i Acarina) dwóch typów łąk
}

\author{
Izabella Olejniczak', Stefan Russel ${ }^{2}$, Anna Prędecka ${ }^{3}$ \\ ${ }^{1}$ Institute of Ecology and Bioethics, Cardinal Stefan Wyszyński University in Warsaw, Poland \\ 2 Faculty of Agriculture and Biology, Warsaw University of Life Sciences (SGGW), Warsaw, Poland \\ ${ }^{3}$ Faculty of Civil Security Engineering, The Main School of Fire Service (SGSP), Warsaw, Poland \\ ORCID: IO https://orcid.org/0000-0003-4746-7874; AP https://orcid.org/0000-0002-7867-8319 • i.olejniczak@uksw.edu.pl
}

\begin{abstract}
IThe impact of prescribed fires in grasslands on soil mesofauna was studied in the field experiment. The study was carried out on two types of meadows: on mineral (meadow I) and organic soils (meadow II), near Warsaw $\left(52^{\circ} 10^{\prime} \mathrm{N} ; 20^{\circ} 50^{\prime} \mathrm{E}\right)$. In November 2007 sampling plots, $1 \mathrm{~m}^{2}$ in size were chosen at random and burned. Soil samples were taken just after fire and in April, July and November, 2008 to the depth of $10 \mathrm{~cm}$ from unburned plots (control), at the edge of fire and in burned plots. The soil mesofauna was extracted from soil samples in the Tullgren apparatus. There were not found any effects of prescribed fires on mesofauna densities. However, a slight increase of mesofauna abundance was observed on burned areas 12 months after experimental fires on the meadow I and decrease on the meadow II. Just after fire, on burned areas, only euedaphic species of Collembola were present among mites communities dominated Oribatida, with thick cuticule.
\end{abstract}

Keywords: experimental fires, Collembola, Acarina, meadows

Streszczenie: Wpływ pożarów doświadczalnych na mezofaunę glebową zbiorowisk trawiastych badano w doświadczeniu polowym. Badania prowadzono na dwóch typach łąk: na glebach mineralnych i organicznych, w okolicach Warszawy $\left(52^{\circ} 10^{\prime} \mathrm{N}\right.$; $20^{\circ} 50^{\prime}$ E).W listopadzie 2007, wybrano losowo i wypalono poletka o powierzchni $1 \mathrm{~m}^{2}$. Próbki gleby poprano tuż po pożarze oraz w kwietniu, lipcu i listopadzie 2008 roku do głębokości $10 \mathrm{~cm}$ w miejscach wypalonych i niewypalonych. Mezofaunę glebową wypłoszono z próbek w aparacie Tullgrena. Nie stwierdzono żadnego wpływu doświadczalnych pożarów na zagęszczenia mezofauny. Jednakże, 12 miesięcy po doświadczalnych pożarach obserwowano nieznaczny wzrost liczebności mezofauny na wypalonych poletkach na łące mineralnej i nieznaczny spadek na łące oragnicznej. Tuż po pożarze, na wypalonych poletkach, były obecne jedynie gatunki euedaficzne Collembola, a w zespołach roztoczy dominowały Oribatida o grubej kutikuli.

Słowa kluczowe: eksperymentalne pożary, Collembola, Acarina, łąki

\footnotetext{
" This article was originally published in Polish Olejniczak, Izabella, Stefan Russel, i Anna Prędecka. 2011. "Wpływ doświadczalnych pożarów na zespoły mezofauny (Collembola i Acarina) dwóch typów łąk." Studia Ecologiae et Bioethicae 9(3): 85-96. The translation of the article into English was financed by the Ministry of Science and Higher Education of the Republic of Poland as part of the activities promoting science - Decision No. 676/P-DUN/2019 of 2 April 2019. Translation made by GROY Translations.
} 


\section{Introduction}

Fires play a huge role in the evolution of ecosystems, shaping their physical and biotic conditions, MacGregor (2006). They affect the biodiversity of ecosystems (Morgan and Lunt 1999; Swengel 2001; Wolfson et al. 2005; Scheintaub et al. 2009).

Several studies have appeared in recent decades on fires and their role in shaping forests and grasslands, but a majority of the studies discuss the impact of fires on vegetation (Daubenmire 1968). The studies have shown that fires in grasslands help to remove accumulated litter and nutrients. They thus increase the productivity of those ecosystems (Knapp and Seastedt 1986; Briggs and Knapp 1995). Hadley and Kieckhefer (1963) have demonstrated greater biomass and productivity of roots on burned prairies rather than on those eaten by herbivores. Undoubtedly, fires affect soil microclimate (Hulberr 1969). With the removal of litter, soil moisture is reduced (Knapp and Seastedt 1986). The temperature at the time of fire depends on the quantity and quality of burned fuel, the properties of soil, especially its humidity and permeability (Fisher and Binkley 2000).

Influence of fires on soil invertebrates, especially mesofauna, is controversial. High temperatures that accompany fires cause the death of invertebrates that inhabit litter and topsoil. Some studies also show the positive effects of fires on various species of invertebrates (Seastedt 1994; Swengel 2001). Mesofauna including springtails (Collembola) and mites (Acari) is found in a huge amount in soil (Seastedt 1984). Collembola and Acari indirectly control soil processes and functioning of ecosystems (Lussenhope 1981). Although there are a lot of studies devoted to fires of grasslands, little is known about their impact on soil mesofauna and its ability to regenerate after the fire (Lussenhope 1976).

Presented results are part of comprehensive research on the impact of fire on the functioning of grasslands.

The aim of the study is to determine the influence of prescribed fires on complexes of soil mesofauna, Collembola and Acari, taking into account the different types of meadows and soil.

\section{Material and methods}

The study was carried out on two types of perennial meadows, hay ones, of the Institute for Land Reclamation and Grassland Farming, near Warsaw $\left(52^{\circ} 10^{\prime} \mathrm{N}\right.$; $\left.20^{\circ} 50^{\prime} \mathrm{E}\right)$. The meadows were situated on two types of soils: mineral (meadow I MI) and organic (meadow II - MII). Table 1 gives a brief description of the meadows. During the study period, the experimental plots, designated on both types of meadows, were not moved.

Table 1. Characteristics of the test meadows.

\begin{tabular}{|c|c|c|}
\hline Characteristic & $\begin{array}{l}\text { Meadow I } \\
\text { (MI) }\end{array}$ & $\begin{array}{l}\text { Meadow II } \\
\text { (MII) }\end{array}$ \\
\hline Type of soil & $\begin{array}{l}\text { mineral, } \\
\text { proper pseudoglay soil, } \\
\text { made of clay sand on till }\end{array}$ & $\begin{array}{l}\text { organic, peat--muck soil produced } \\
\text { of low peat }\end{array}$ \\
\hline $\begin{array}{l}\text { Dominant } \\
\text { plant species } \\
\text { (participation } \\
\text { in phyto- } \\
\text { cenosis) }\end{array}$ & $\begin{array}{l}\text { perennial ryegrass } \\
\text { Lolium perenne L. } \\
\text { (51\%) } \\
\text { tall oat-grass Arrhena-therum } \\
\text { elatius (L.) } \\
\text { P. Beauv. ex } \\
\text { J. \& C. Presl } \\
\text { (27\%) }\end{array}$ & $\begin{array}{c}\text { reed canarygrass } \\
\text { Phalaris arundinacea L. (49.7\%) } \\
\text { wood bulrush } \\
\text { Scirpus sylvaticus L. } \\
(31.7 \%)\end{array}$ \\
\hline
\end{tabular}


In November 2007, experimental plots of $1 \mathrm{~m}^{2}$ were selected on tested meadows where prescribed fires were carried out. On each plot, $50 \mathrm{~g}$ of grass litter was spread and burned and the surface temperature of the soil was measured immediately after the fire. Average temperatures were: in case of Meadow I (MI) $-477^{\circ} \mathrm{C}$, and Meadow II (MII) $-473^{\circ} \mathrm{C}$. The material was collected immediately after the experimental fires and also in April, July and October of the following year. Each time the soil samples were taken using steel corer of the diameter of $2.5 \mathrm{~cm}$ at a depth of 0-10 cm, from unburnt areas (control - C), at the edge of the fire (E) and burned areas (F). Mesofauna from collected soil samples was extracted in Tullgren's apparatus. Springtails were divided into three ecological groups due to their presence in soil layers: epigeon- a group of species found on a soil surface, hemiedaphone - a group of species found in litter and a top layer of soil and euedaphon - a group of species found in deeper layers of soil (Christiansen 1964).

Nonparametric tests were used to analyse the material: Wilcoxon test of rank difference for pairs - a comparison of averages and a nonparametric analysis of ANOVA Kruskal-Wallis of variance to determine the influence of factors of an experiment.

\section{Results and discussion}

The mesofauna densities were different in the experimental plots in both types of meadows. Immediately after prescribed fires, there were no significant differences in density between the burned plots, the fire edge and the unburned area - control in both Collembola and Acari case, regardless of soil type (Table 2). The time of the experimental burning of the litter of the plots of the tested meadows and the soil type were important factors for the formation of mesofauna density (Table 2).
Table 2. An impact of the factors of the experiment on Collembola (A) and Acari (B) density (ANOVA Krusal-Wallis $\mathrm{H}$ test) (* the analysis includes areas: burnt area, fire boundary and unburnt area - control; *:* the analysis takes into account following periods: immediately after the experimental fire and the subsequent months of collecting samples - 6, 9 and 12 months after the fire). df - degrees of freedom.

\section{A. Collembola}

\begin{tabular}{|c|c|c|c|}
\hline Factor & Value $\mathrm{H}$ & df & $\begin{array}{l}\text { Significance } \\
\text { of differences }\end{array}$ \\
\hline Type of soil & 5.46 & 1 & $\mathrm{p}=0.02$ \\
\hline Location* & 0.12 & 2 & $\mathrm{p}=0.9$ \\
\hline Time $e^{* * *}$ & 12.4 & 3 & $\mathrm{p}=0.006$ \\
\hline \multicolumn{4}{|l|}{ B. Acari } \\
\hline Factor & Value $\mathrm{H}$ & df & $\begin{array}{l}\text { Significance } \\
\text { of differences }\end{array}$ \\
\hline Type of soil & 5.46 & 1 & $\mathrm{p}=0.02$ \\
\hline Location* & 0.78 & 2 & $\mathrm{p}=0.7$ \\
\hline Time $e^{* * *}$ & 21.52 & 3 & $\mathrm{p}=0.001$ \\
\hline
\end{tabular}

Although no significant differences were found in the average density of mesofauna, some certain regularities in their course can be found (Fig. 1, 2, 3 and 4). A decline of mesofauna number was observed on a meadow on organic soil) (MII) 12 months after the experimental fire (Fig. 2 and Fig. 4 ), while on a meadow situated on mineral soil there was an increase of the amount (Fig. 1 and Fig. 3). It can also be noticed that the density of mesofauna was slightly lower on a meadow on organic soil than on a meadow on mineral soil. This trend was clearer in the case of Acari than in Collembola (Fig. 1, 2, 3 and 4). 


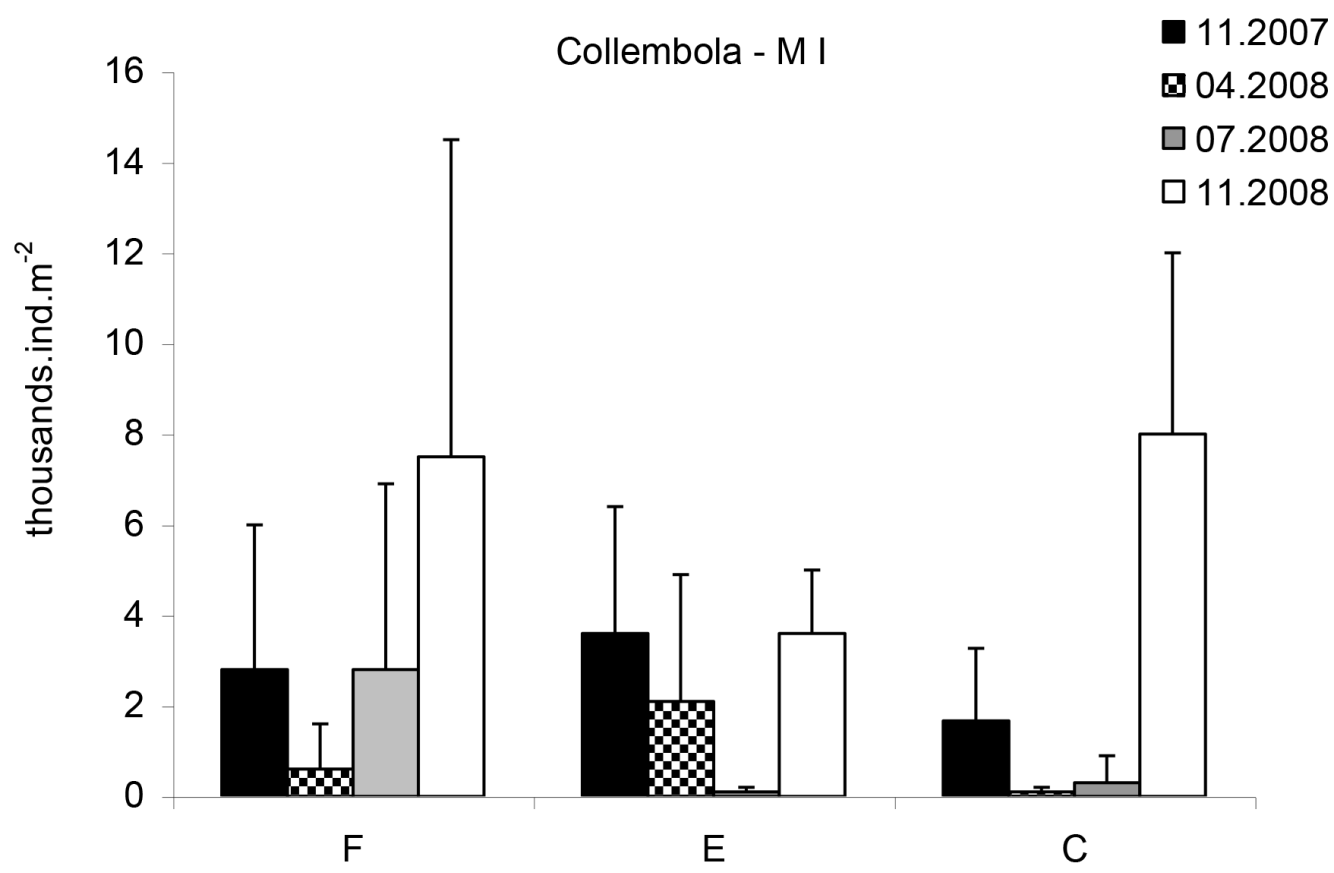

Fig. 1. Collembola density on a plot, on a meadow situated on mineral soil (MI) immediately after the experimental fire and in the following months: April 2008 (6 months after the fire), July ( 9 months after the fire) and November (12 months after the fire). F - burned site, $\mathrm{E}$ - edge of burned site, $\mathrm{C}$ - unburned site, control.

\section{Collembola - M II}

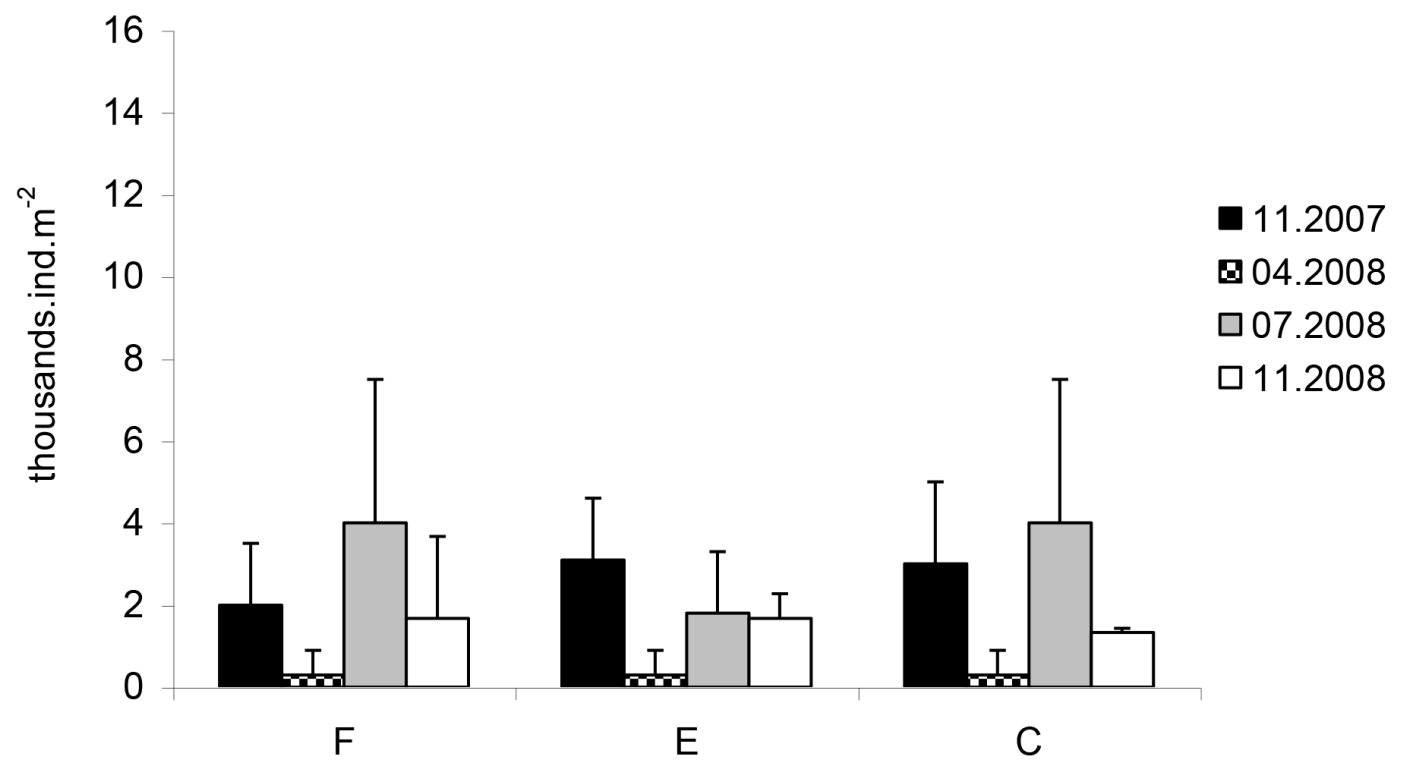

Fig. 2. Collembola density on a plot, on a meadow located on organic soil (MII) immediately after an experimental fire and in the following months: April 2008 (6 months after the fire), July ( 9 months after the fire) and November (12 months after the fire). F - burned site, $\mathrm{E}$ - edge of burned site, $\mathrm{C}$ - unburned site, control. 


\section{Acari - M I}

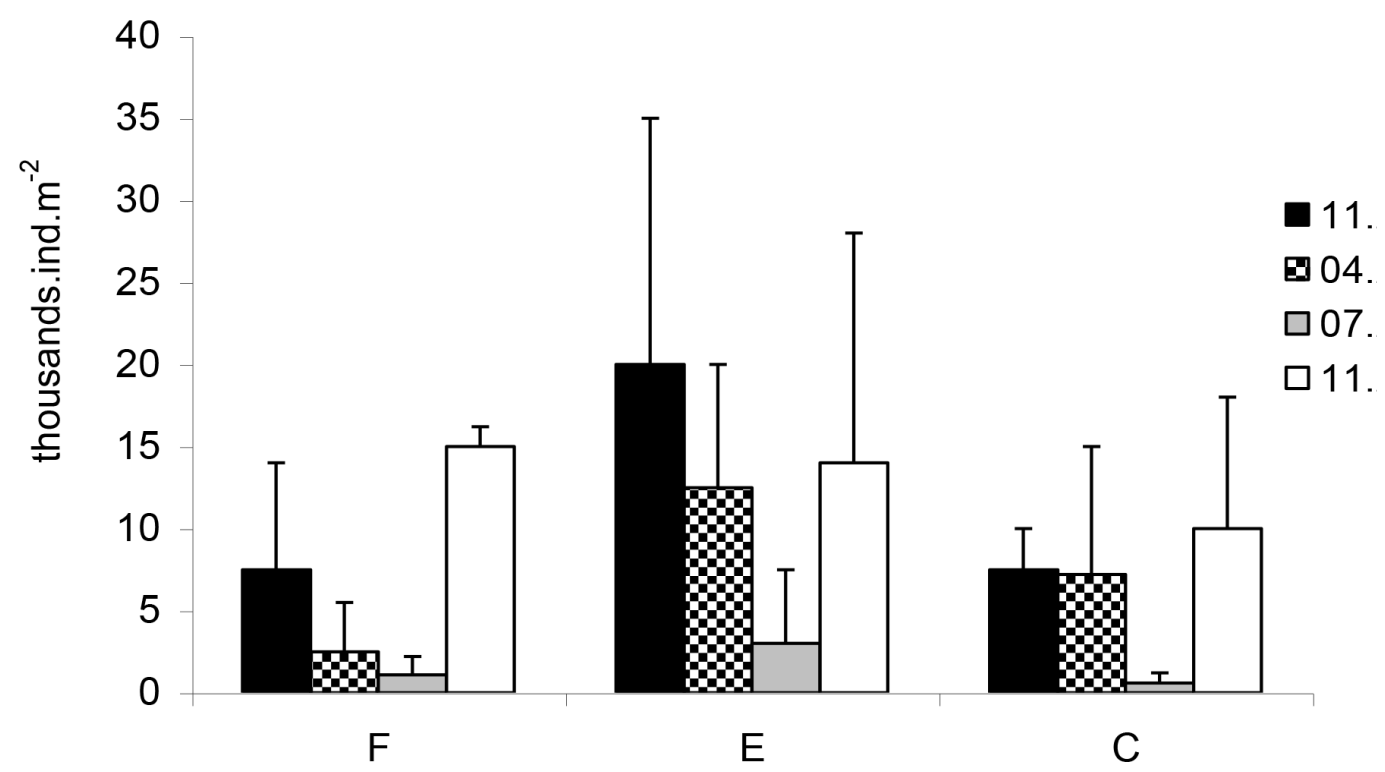

Fig. 3. Acari density on a plot, on a meadow located on mineral soil (MI) immediately after the experimental fire and in the following months: April 2008 (6 months after the fire), July ( 9 months after the fire) and November (12 months after the fire). F - burned site, $\mathrm{E}$ - edge of burned site, $\mathrm{C}$ - unburned site, control.

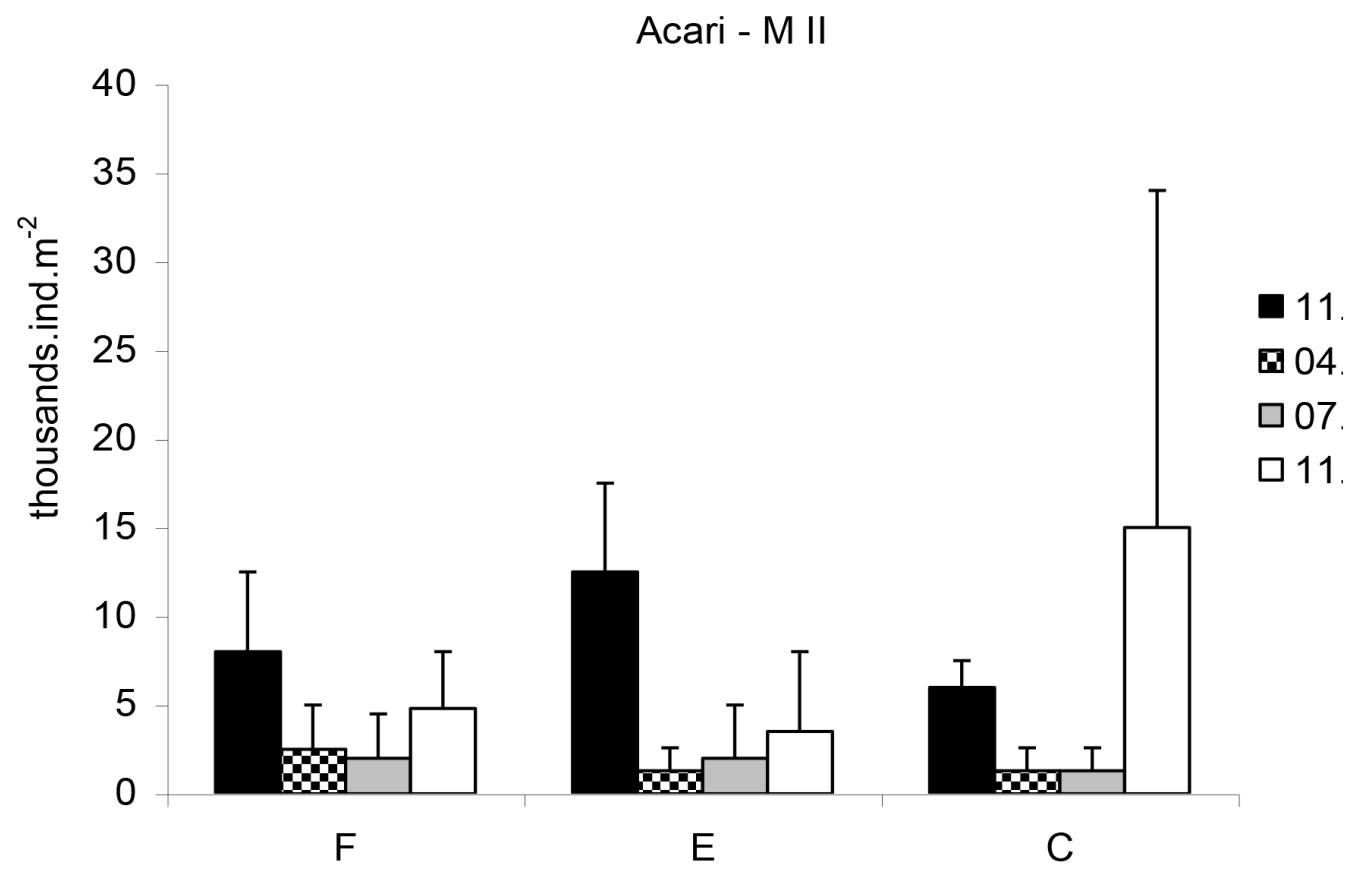

Fig. 4. Acari density on a plot, on a meadow located on organic soil (MII) immediately after an experimental fire, and in the following months: April 2008 (6 months after the fire), July ( 9 months after the fire) and November (12 months after the fire). $F$ - burned site, $E$ - edge of burned site, $C$ - unburned site, control. 


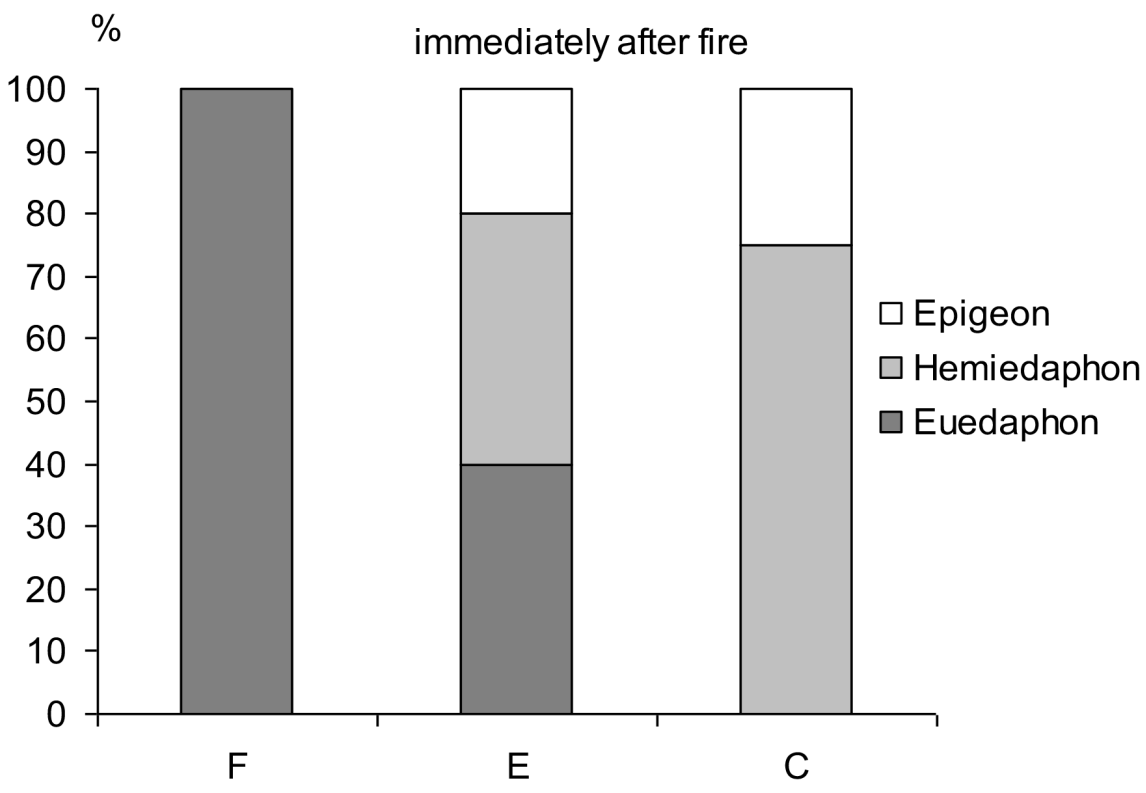

Fig. 5. The share of ecological groups of Collembola communities on a meadow located on mineral soil (MI)) immediately after the experimental fire. F - burned site, $\mathrm{E}$ - edge of burned site, $C$ - unburned site, control.

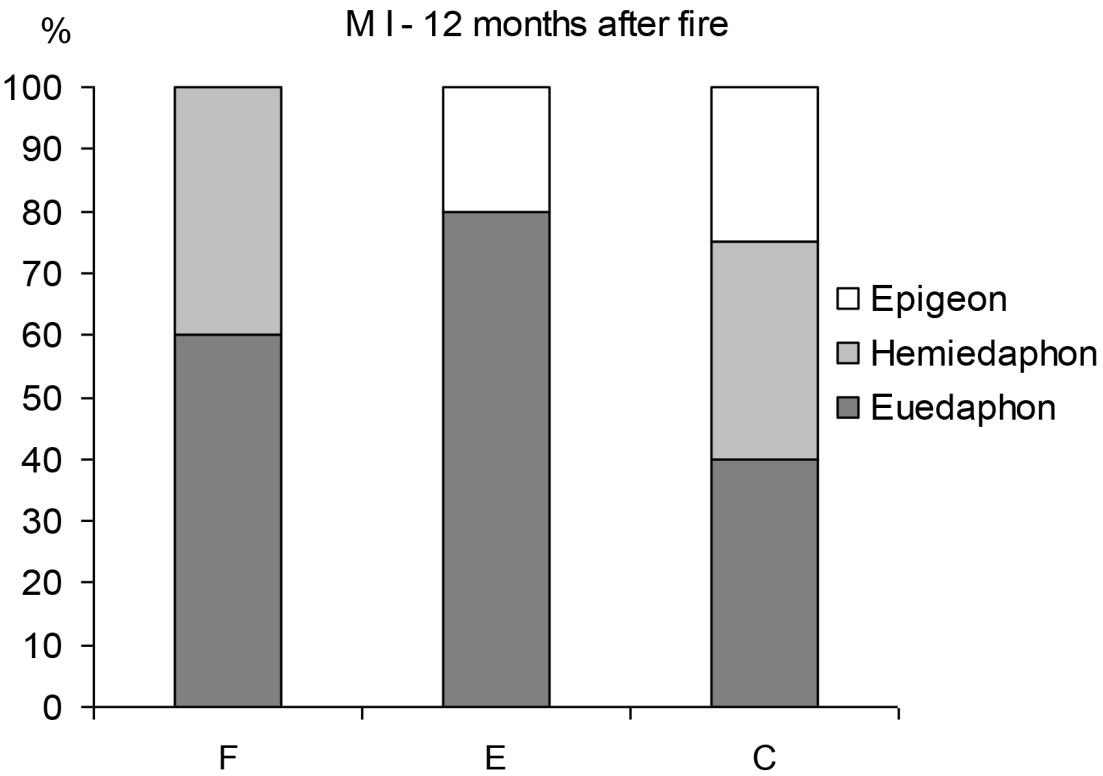

Fig. 6. The share of ecological groups of Collembola communities on a meadow located on mineral soil (MI) after 12 months after an experimental fire. F - burned site, $\mathrm{E}$ - edge of burned site, $C$ - unburned site, control.

The number of different ecological groups of springtails of examined meadows was different. However, regardless of the type of soil where the grasslands were located, only euedaphic species were pres- ent immediately after the prescribed fire (Fig. 5 and Fig. 7). Within 12 months of the experimental fires, apart from euedaphic also hemiedaphic and epigeic species appeared (Fig. 6 and Fig. 8). 
$\%$

100

90

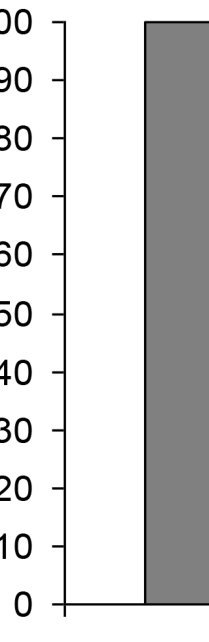

M II - immediately after fire

\section{$\mathrm{F}$}

E

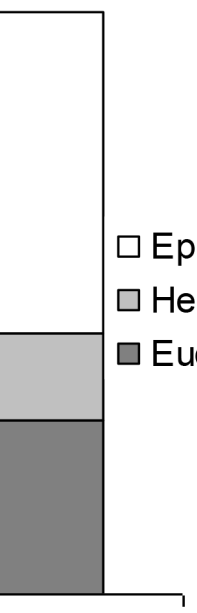

C

Fig. 7. The share of ecological groups of Collembola communities on a meadow located on organic soil (MII) immediately after the experimental fire. F - burned site, E - edge of burned site, $\mathrm{C}$ - unburned site, control.

$\%$

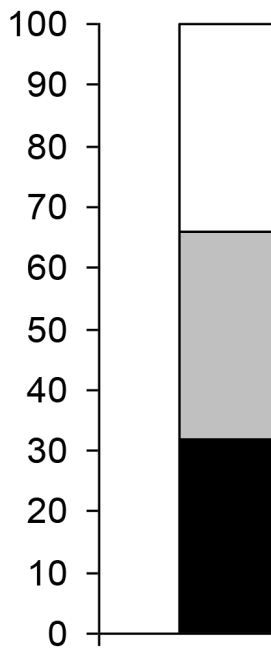

$\mathrm{F}$

M II - 12 months after fire

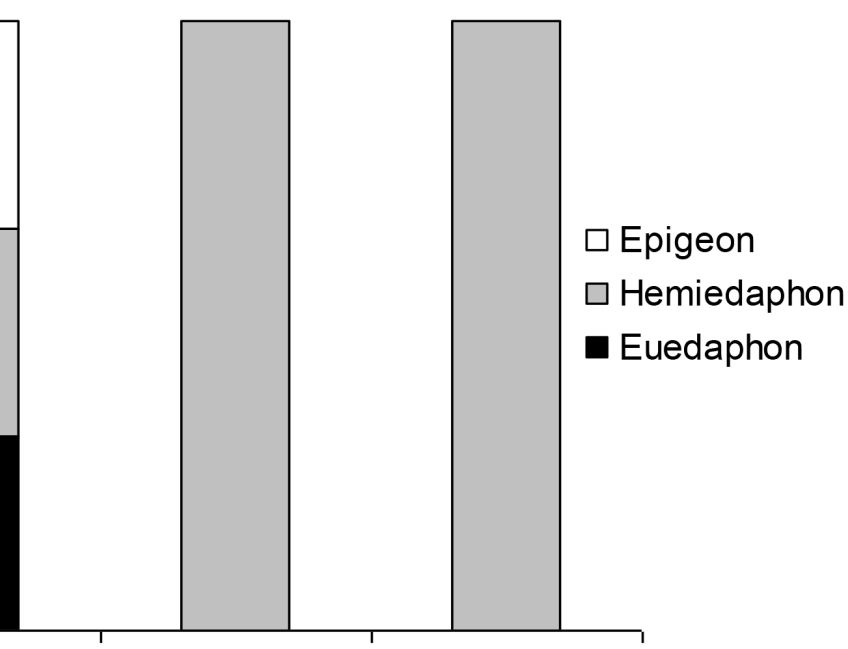

$\mathrm{E}$

C

Fig. 8. The share of ecological groups of Collembola communities on a meadow located on organic soil (MII) after 12 months of experience of fire. F - burned site, $E$ - edge of burned site, C - unburned site, control.

Contrary to the results of Wikars and Schimmel (2001), who observed a drastic decline in mesofauna number as a result of fires, there was no clear negative effect of fire on Acari and Collembola density in the presented study. Similar results were ob- tained by Pomeroy and Rwakaikara (1975) in their study on the effects of African savannah fires on soil invertebrates.

This can be explained, on the one hand, by the physiological adaptations of the studied mesofauna groups and their escape 
possibilities, on the other hand, by the nature of the prescribed fires. The majority of mesofauna live in the top layer of soil and mulch (Hågvar 1983). For the majority of springtails and mites, the temperature causing their death has been discovered to be between $35-40^{\circ} \mathrm{C}$ (Tribaud 1977a, b). Vannier (1994) showed in his research that optimum temperatures for insect development range from $20^{\circ} \mathrm{C}$ to $50^{\circ} \mathrm{C}$. Additionally, he stated that species living in the litter and the topsoil are characterised by greater tolerance to high temperatures than those found in deeper layers of soil. Fast spreading fires, such as those of grasslands, consume less fuel and therefore have an insignificant influence on a change of soil temperature.

An ability to survive small fires (such as the one present in the study) by soil mesofauna is also related to the ability to actively avoiding them. Collembolan, especially epigeic ones, have the ability to move quickly and can escape fire. This fact is confirmed by a larger number of those invertebrates on the edge of fire that was recorded immediately after the prescribed fire presented in the study. Euedaphic species living in deeper soil layers are usually not exposed to high temperatures. Therefore, only euedaphic species have been found on the burned plots. Acari, they can survive fires, among other things, thanks to their thick cuticula. Pomeroy and Rwakaikara (1975) stated that the effects of fire may be stimulating for Acari, causing an increase in their numbers.

In the presented research it was stated that the impact of fires on soil mesofauna depends on a type of soil. Fires significantly alter soil properties. They contribute to its overdrying and exposure to intense sunlight (Hulberr 1969; Knapp and Seastedt 1986). Muck-peat soils are particularly sensitive to overdrying. Acari and especially Collembola are sensitive to the humidity of the environment, hence probably the reduction in density of those invertebrates recorded on burnt fields after a year from experimental fires.

Obtained results indicate the possibility of regeneration of soil mesofauna communities in a relatively short time after the fire. However, further research is needed.

\section{Bibliography}

Briggs, John, and Alan Knapp. 1995. "Interannual variability in primary production in tallgrass praire - climate, soil moisture, topographic position and fire as determinants of aboveground biomass." American Journal of Botany 82(8): 1024-1030. https://doi. org/10.1002/j.1537-2197.1995.tb11567.x.

Christiansen, Kenneth. 1964. "Bionomics of Collembola." Annual Review of Entomology 9(1): 147-178.

Daubenmire, Rexford. 1968. "Ecology of fire in grasslands." Advances in Ecological Research 5: 209-266. https://doi.org/10.1016/S00652504(08)60226-3.

Fisher, Robert, and Dan Binkley. 2000. Ecology and Management of Forest Soils. New York: Wiley.

Hadley, Elmer, and Barbara Kieckhefer. 1963. "Productivity of two praire grasses in relation to fire frequency." Ecology 44(2): 389395. https://doi.org/10.2307/1932186.

Hågvar, Sigmunt. 1983. "Collembola in Norvegian coniferous forest soils II. Vertical distribution." Pedobiologia 25(6): 383-401.

Hulberr, Lloyd. 1969. "Fire and litter effects undisturbed bluestem preirie in Kansas." Ecology 50: 874-877. https://doi. org/10.2307/1933702.

Knapp, Alan, and Tim Seastedt. 1986. "Detritus accumulation limits productivity of tallgrass praire." Bioscence 36(10): 662-668.

Lussenhop, John. 1976. "Soil arthropod response to prairie burning." Ecology 57(1): 8898. https://doi.org/10.2307/1936400.

Lussenhop, John. 1981. "Microbial and microarthropod detrital processing in a prairie soil." Ecology 62(4): 964-972. https://doi. org/10.2307/1936995.

MacGregor, Donald. 2006. "The future of fire in environmental management." Futures 38(4): 505-518. https://doi.org/10.1016/j.futures.2005.07.015.

Morgan, John, and Ian Lunt. 1999. "Effects of time-since-fire on the tussock dynamics of a dominant grass (Themeda triandra) in a temperate Australian grassland." Biological Conservation 88(3): 379-386. https://doi. org/10.1016/S0006-3207(98)00112-8.

Pomeroy, Derek, and Derek Rwakaikara. 1975. "Soil arthropods in relation to grassland 
burning." East African Agricultural and Forestry Journal 41(2): 114-118. https://doi.org/ 10.1080/00128325.1975.11662786.

Scheintaub, Mary, Justin Derner, Eugene Kelly, and Alan Knapp. 2009. "Response of the shortgrass steppe plant community to fire." Journal of Arid Environments 73(12): 1136-1143. https://doi.org/10.1016/j.jaridenv.2009.05.011.

Seastedt, Tim. 1984. "The role of microarthropods in decomposition and mineralization processes." Annal Review of Entomology 29(1): 25-46.

Seastedt, Tim. 1994. "Belowground macroarthropods of annually burnt and unburnt tallgrass praire." American Midland Naturalist 111(2): 405-408. https://doi.org/10.2307/2425336.

Swengel, Ann. 2001. "A literature review of insect responses to fire, compared to other conservation managements of open habitat." Biodiversity and Conversation 10(7): 1141-1169. https://doi.org/10.1023/A:1016683807033.

Tribaud, Jean-Marc. 1977a. "Intermue ettemperatures lethales chez les insects collemboles arthropleones. I. - Hypogastruridae et Onychiuridae." Revue d'écologie et de biologie du sol 14: 45-61.
Tribaud, Jean-Marc. 1977b. "Intermue ettemperatures lethales chez les insects collemboles arthropleones. II. - Isotomidae, Entomobryidae et Tomoceridae." Revue d'écologie et de biologie du sol 14: 267-278.

Wikars, Lars-Ove, and Johnny Schimmel. 2001. "Immediate effects of fire-severity on soil invertebrates in cut and uncut pine forests." Forest Ecology and Management 141(3): 189-200. https://doi.org/10.1016/ S0378-1127(00)00328-5.

Wolfson, Barbara, Thomas Kolb, Carolyn Sieg, and Karen Clancy. 2009. "Effects of post-fire conditions on germination and seedling success of diffuse knapweed in northern Arizona." Forest Ecology and Management 216(13): 342-358. https://doi.org/10.1016/j.foreco.2005.05.047.

Vannier, Guy. 1994. "The thermobiological limits os some freezing intolerant insects: the supercooling and thermostupor points." Acta Oecologica 15(1): 31-42. 